\title{
An Approach to Seismic Analysis of (Engineered) Buildings in Sri Lanka
}

\author{
C. S. Lewangamage and H. G. S. R. Kularathna
}

\begin{abstract}
Even though, Sri Lanka was believed to have no seismic threats, it is now realized that Sri Lanka can no longer be considered as a country safe from seismic threats following the recent events that occurred in and around the island.
\end{abstract}

The present study is therefore aimed at providing guidance on suitable analysis procedure for buildings in Sri Lanka where the seismic consideration is explicitly warranted for a structure. The proposed guidelines in this study are based on Euro Code 8 (EN 1998-1: 2004): "Design of Structures for Earthquake Resistance". Euro Code 8 was selected for this purpose as it allows national choices in defining seismic characteristics such as peak ground accelerations, response spectra, etc. in seismic design procedure. This study mainly focuses on these national choices and suitable values are proposed and discussed, depending on the available seismic data in Sri Lanka. Whenever there is a lack of data, suitable approaches are suggested comparing similar seismic codes such as IS 1893-1: 2002 and AS 1170.4: 2007.

Finally, two case studies are carried out in order to illustrate how the developed guidelines can be used in the seismic design procedure of buildings particularly in Sri Lanka.

Keywords: Intra-plate earthquake, seismic design guidelines, Sri Lankan National Choices to EC 8.

\section{Introduction}

It is a well known fact that Sri Lanka is located within the Indo-Australian tectonic plate and it is far away from the plate boundaries (See Figure.1). The inter-plate earthquakes which take place along these boundaries are the most common and are clearly identified. However, the location of Sri Lanka would cause rare chances of occurrence of such inter-plate earthquake. Therefore, Sri Lanka was considered to have no seismic threats.

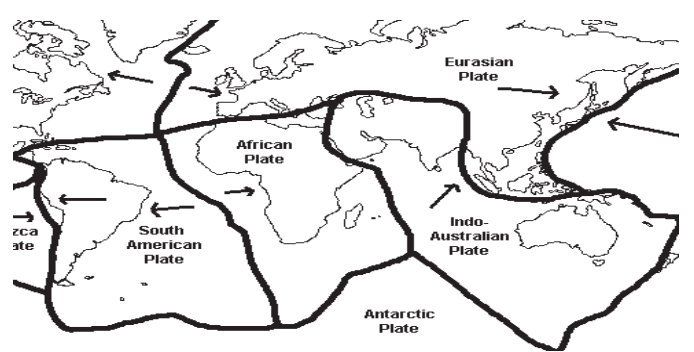

Figure 1 - Tectonic plate boundaries

However, Sri Lanka cannot be ignored regarding earthquake risks because; intra-plate earthquakes that take place within the tectonic plates causing significant damages are still possible. The intra-plate type earthquakes can occur at any place without a warning. A good example is the earthquake (5.9 on Richter scale) that hit New-castle Australia. This region wasearlier considered as a no-risk area. The damage caused was 4 billion Australian Dollars. Therefore, the seismic threats to Sri Lanka can no longer be ignored and the necessity for designing structures for possible seismic hazards in Sri Lanka must be identified.

However, no comprehensive studies have been carried out to develop seismic analysis and design guidelines for buildings in Sri Lanka. The only available document for this purpose is "Earthquake resistant detailing for buildings in Sri Lanka" published by the Society of Structural Engineers, Sri Lanka. Therefore, there is a strong need to establish a national building analysis and draw up design guidelines for possible seismic loads in Sri Lanka.

\section{Literature Review}

The evolution of the seismic design procedure can be summarized in three main phases [1]. The historic approach is to assume the design seismic forces to be proportionate to the seismic mass of the structure.

Eng. (Dr.) C.S. Lewangamage, B.Sc. Eng. Hons(Moratuwa),

M.Eng. (Tokyo), Ph.D (Tokyo), C. Eng., MIE(Sri Lanka),

Senior Lecturer in Civil Engineering, Department of Civil

Engineering, University of Moratuwa, Sri Lanka

Ms. H.G.S.R.Kularathna, B.Sc.Eng.Hons(Moratuwa), M.Sc (Moratuwa), Ph.D candidate, University of Cambridge, UK 
In the conventional code approach these design seismic forces are calculated as inertial forces induced by the ground acceleration. Both these approaches are based on the force based design concept. However, the future trend is to adopt a displacement based design approach where the non-linear response of the structure is largely taken into account.

The modern seismic codes systematically adopt new design concepts such as performance based design methods and non-linear analysis methods. Nevertheless, they still use force based design approach while some of the codes are now trying to adopt displacement based design methods. In this review, conventional force based design approach was studied given in four main seismic standards namely US standards (Federal Emergency Management Agency - FEMA 450: NEHRP Recommended Provisions for Seismic Regulations for New Buildings and Other Structures [2]) and Euro Code 8 (EN 1998-1: 2004) [3], Australian standard (AS 1170.4: 2007) [4] and the Indian standard (IS 1893-1: 2002) [5]. All these codes follow generally a similar procedure (See Figure .2) but with some differences unique to their region such as seismicity, soil condition, etc.

\subsection{Target performance level}

FEMA 450-2: 2003 Commentary [6] discusses explicitly the target performance levels associated with the provisions given in FEMA 450-1. It is expected that structures designed and constructed in accordance with the provisions will generally be able to meet a number of performance criteria when subjected to earthquake ground motions of differing severity. The ground motion levels are defined in terms of their probability of exceedance. There are mainly four performance levels associated with these guidelines. They are operational, immediate occupancy, life safety and collapse prevention levels.

Euro Code 8 (EN 1998-1:2004) establishes two fundamental performance requirements as the No-collapse requirement and Damage limitation requirement. However, within the framework of Euro codes the concept of limit state design is still the basis and therefore, the above two performance requirements lie within the two limit states, the ultimate limit state and serviceability limit state. Nevertheless, as indicated by the above requirements, these two performance levels are to be checked against two different levels of the seismic action, interrelated by the seismicity of the region.

\subsection{Specification of hazard and defining seismic action}

Each code specifies the design seismic action in terms of spectral ordinates with different definitions and terminologies. In Euro Code 8 the seismic hazard at the site is defined by the Peak Ground Acceleration (PGA) for rock site and it is termed as the 'reference' peak ground acceleration for 475 year return period earthquake. The response acceleration values for the design of buildings are then represented by an elastic response spectrum. Australian standard (AS 1170.4:2007) defines the seismic hazard by peak ground acceleration similar to the EC 8 but termed as hazard factor (Z) for 500 return period of earthquake and elastic response spectra are defined to obtain the spectral acceleration value used for designing structures.

\begin{tabular}{|c|}
\hline Define target performance level \\
\hline How buildings perform during and after earthquake, Building classification \\
\hline Specification of hazard and Define seismic action \\
\hline Ground motion for which buildings are designed \\
\hline \\
\hline Structural analysis and design criteria \\
\hline Structural type, shape and configuration, structural analysis methods, design and detailing \\
\hline
\end{tabular}

Figure 2 - General seismic design procedure common to seismic codes 
A similar approach is given in the Indian seismic standard as well, where the seismic hazard is defined by means of peak ground acceleration term as zone factor ( $\mathrm{Z}$ ) associated with maximum considered earthquake. The response spectrum is given for obtaining response acceleration of buildings in the designing process.

However, within the framework of FEMA 450 the ground motion hazards are defined in terms of maximum considered earthquake ground motions which are then presented within the provisions in terms of the mapped values of the spectral response acceleration at short periods, $\mathrm{S}_{\mathrm{s}}$, and at 1.0 second, $\mathrm{S}_{1}$, for a particular soil type. The structural design is performed for earthquake demands that are $2 / 3$ of the maximum considered earthquake response acceleration and design response spectra as required in the design process to obtain the response acceleration for buildings are given.

\subsection{Structural analysis and design criteria} After selecting the ground motion, the codes present a systematic procedure to design buildings to resist the ground motion. These provisions are based on structural dynamics and hence are similar in their concept. However, the advancement of the seismic design concepts might be different in different codes. Each code specifies a preliminary screening process which decides basically the need for seismic design for a particular building, suitable structural analysis method such as linear/non-linear and static/dynamic and so forth.

\section{Seismic Hazard Assessment for Sri Lanka}

It is the conventional approach that the seismic hazard for a country is specified in terms of the peak ground acceleration. It is generally given by the seismic hazard map which divides the country into several seismic zones each having different peak ground acceleration values. For Sri Lanka, such seismic zonation map is not available in order to obtain the ground motion values at each location. But two important studies which propose ground motion values in Colombo area can be identified.

Peiris [7] proposes the best estimate horizontal peak ground acceleration curve with associated confidence intervals (See Figure.3). It shows that the peak ground acceleration at rock site for a $10 \%$ probability of exceedance in 50 years or 475 years return period is around $0.026 \mathrm{~g}$ for Colombo. It also proposes that this value can be used for the whole island since the single seismic source zone used in the PSHA includes Sri Lanka.

Uduweriya et al [8] presents a reliable seismic hazard assessment in Colombo area based on probabilistic approach and proposes a value of $0.1 \mathrm{~g}$ as the peak ground acceleration at rock site for $10 \%$ probability of exceedance in 50 years (i.e. for 475 year return period).

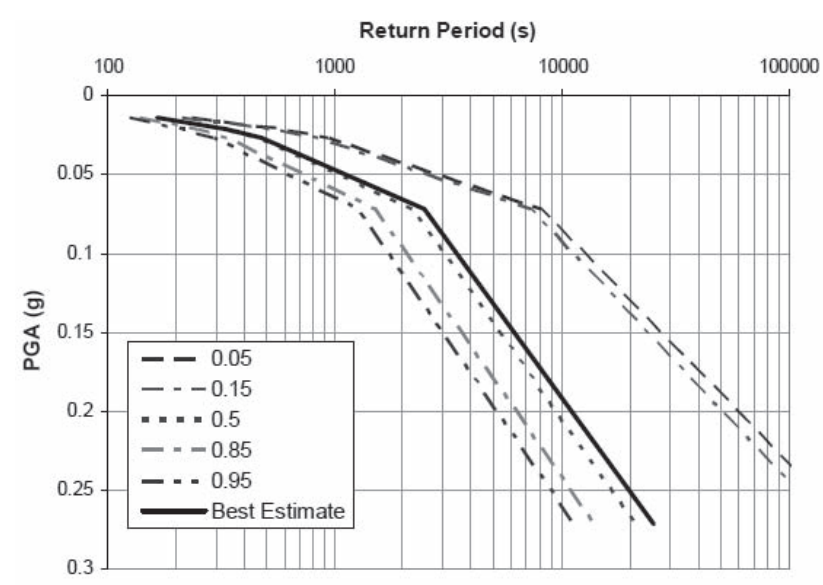

Figure 3 - Hazard curves for Colombo[7]

The above two studies show explicitly different values for the peak ground acceleration at rock site for 475 years return period. However, when these two studies are reviewed the latter study seems to be proved by the other on-going studies in the same subject. Therefore, the reference peak ground acceleration at rock site $\left(a_{g, R}\right)$ is taken to be $0.1 \mathrm{~g}$ for Colombo area. As there is no any other study that considers the whole island, the same peak ground acceleration value $(0.1 \mathrm{~g})$ is used for the buildings in other parts of Sri Lanka.

\section{SriLankan Approach to Euro Code 8}

4.1 Use of EC 8 as the basis for seismic analysis of (engineered) buildings in Sri Lanka

Design of structures to resist earthquake is being developed for many years and still new researches are undertaken all over the world to improve the buildings performance in the event of an earthquake. In Sri Lankan context, it is at its early stage and therefore, it is necessary to make use of well-established seismic design procedures used in other countries as they have carried out lots of studies and gained enormous experience in this field. Hence, it was compromised to use Euro code 8 (EN 1998-1: 
2004): Design of Structures for Earthquake Resistance as the basis for seismic design of buildings in Sri Lanka.

There are mainly two important reasons for selecting the Euro Code 8 for the purpose of developing national guidelines for seismic analysis and design of buildings in Sri Lanka. They are,

- The future trend is to use Euro Codes as the design standards for structures in Sri Lanka. Hence, using the Euro code for the seismic design of buildings in Sri Lanka would be consistent with the future of the design standards in Sri Lanka.

- Euro Code 8 allows national choices for parameters defining local seismic characteristics as well as the methods for designing of buildings for local seismic action. A national annex to Euro Code 8 can be easily developed with the inclusion of local characteristics.

In adopting the Euro code 8 in a country, there are a set of parameters to be determined nationally which accounts for the seismic hazards of the country. Among them, the most imperative parameters are the design seismic action in terms of design peak ground acceleration for different types of structures and the elastic response spectra which is used in the seismic analysis procedure of a structure. In this study, those two parameters are given special consideration and suitable values are recommended based on the available limited seismic data.

Based on the identified seismic hazard levels in Sri Lanka, a suitable approach to seismic analysis procedure (See Figure 4) is proposed according to the Euro Code 8. It is noted that in this study, only linear elastic analysis are considered.

\subsection{Design seismic action}

The structures are designed for different design seismic actions in terms of return period or the probability of exceedance depending on the importance of the building in the event of an earthquake. The structures are classified into four categories as shown in Table 1. The importance Class I includes the structures which do not require an explicit seismic consideration in the design process. The importance Class II, III and IV include the structures identified as important during an earthquake considering their function, the consequences of failure and the economic aspects. Therefore, importance Class II, III and IV buildings are recommended to be designed for possible seismic events (See Figure 4) and hence, the peak ground acceleration values need to be provided.

According to the proposed methodology in Figure 4, a seismic action of 475 year return period is recommended for buildings of importance Class II. For importance Class III buildings, a seismic action of 1500 year return period and for importance Class IV buildings, a 2500 year return period are proposed. However, the peak ground acceleration values for the above seismic actions are not yet determined and therefore the importance factor $\left(\mathrm{V}_{1}\right)$ described in EC 8 can be used to obtain an approximate value for PGA values for 1500 and 2500 year return periods from the PGA value for 475 year return period as it is the only known PGA value for Sri Lanka which is recommended as $0.1 \mathrm{~g}$. The peak ground acceleration for 1500 and 2500 year return periods are obtained by multiplying the above selected peak ground acceleration value for 475 year return period $\left(\mathrm{ag}_{\mathrm{g}, 475)}\right.$ by importance factors $\left(\gamma_{1}\right)$ assigned to the importance Class III and IV buildings as given in Eq.1.

$$
a_{g, 1500 / 2500}=a_{g, 475} \cdot \gamma_{1}
$$

The importance factors are determined using the approximate relationship (Eq.2) given in EN $1998-1 / 2.1[3]$ as.

$\gamma_{1} \sim\left(T_{L R} / T_{L}\right)^{-1 / k}$

Where, $T_{L R}$ is the reference return period (475 years in this case) and $T_{L}$ is defined as the return period in which the same probability of exceedance as in the $T_{L R}$ years is achieved. The exponent $k$ is dependent on the seismicity associated with the country, but EC 8 specifies that it is generally in the order of 3 . This relationship is illustrated for three different $k$ (2.5, 3.0 and 4.0) values in Figure 5 and Table 2 shows the required importance factors for the return periods specific to each importance class of the structures. 


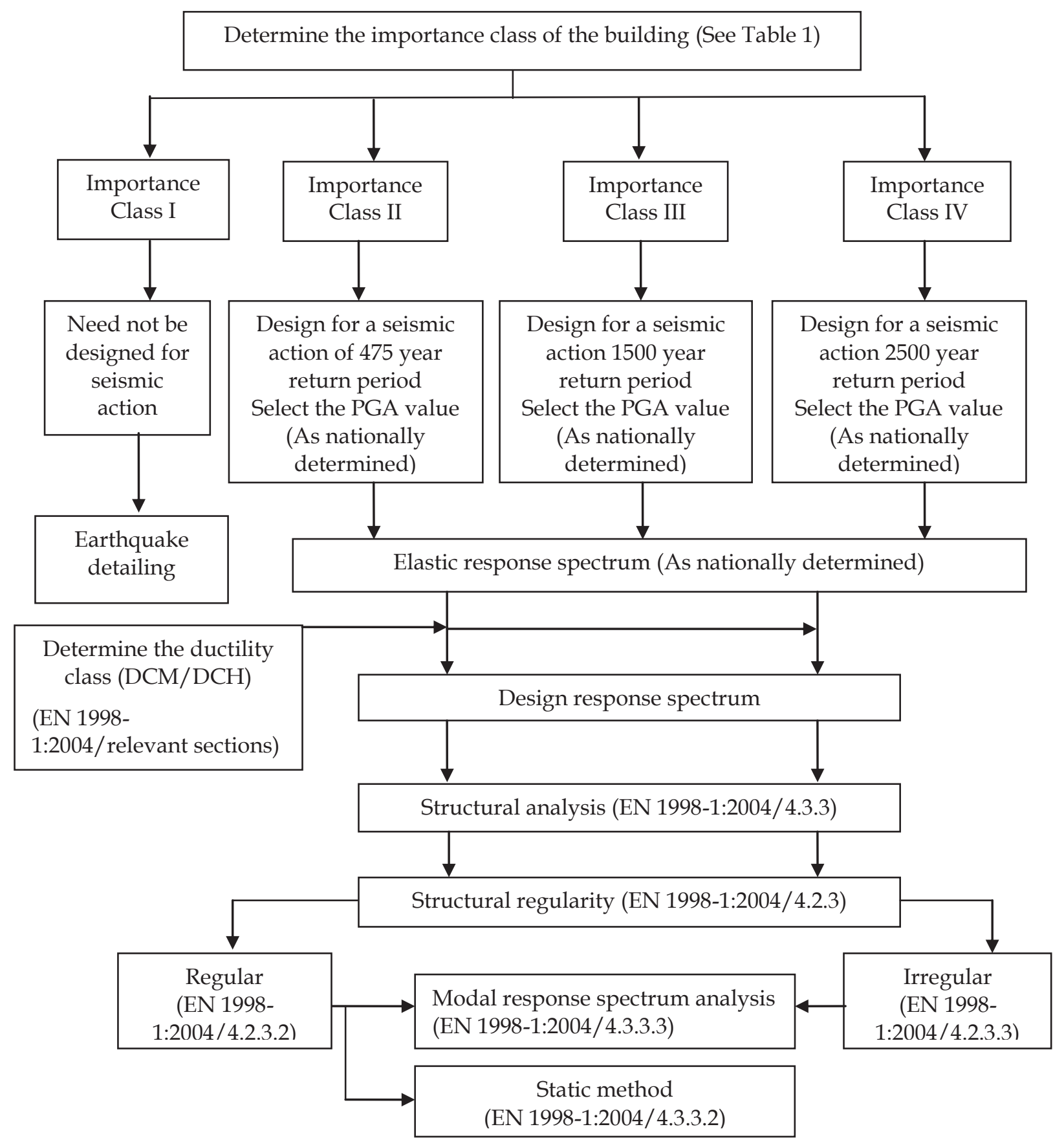

Figure 4 - Proposed seismic analysis approach for Sri Lanka

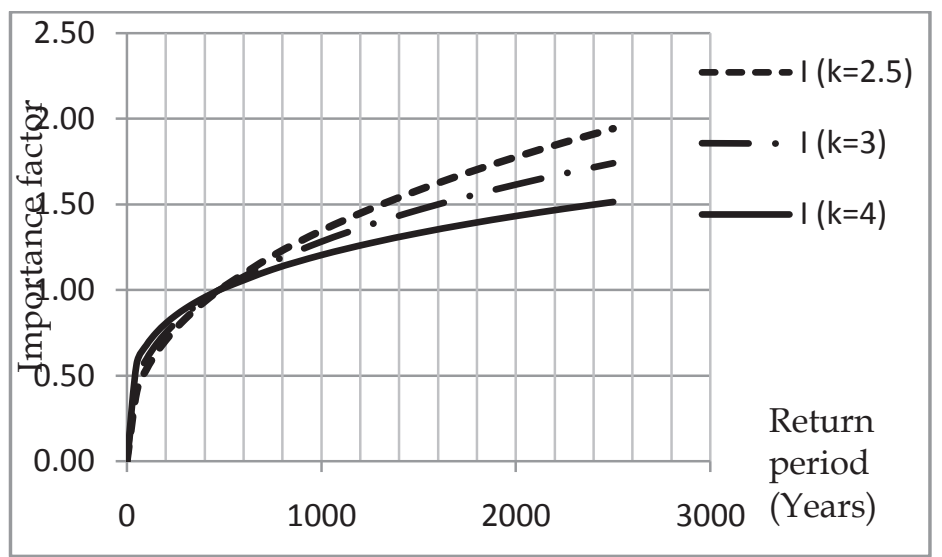

Figure 5 - Representation of the relationship between the importance factor and the return period for different values of the seismic exponent 
Table 1 -Proposed building classification and importance classesbased on the guidelines given in [4] and [5]

\begin{tabular}{|c|c|c|}
\hline $\begin{array}{l}\text { Importance } \\
\text { Class }\end{array}$ & Classification & Examples \\
\hline I & $\begin{array}{l}\text { Buildings of minor } \\
\text { importance for safety of } \\
\text { public and other } \\
\text { property }\end{array}$ & $\begin{array}{l}\text { Agricultural buildings, isolated structures, } \\
\text { domestic structures }\end{array}$ \\
\hline II & $\begin{array}{l}\text { Buildings of low- } \\
\text { moderate importance } \\
\text { for safety of public and } \\
\text { other properties }\end{array}$ & $\begin{array}{l}\text { Hotels, offices, apartment buildings of less than } 10 \\
\text { storeys high, Factories up to } 4 \text { storeys high } \\
\text { Car parking buildings, Shopping centres less than } \\
10,000 \mathrm{~m}^{2} \text { gross area, Public assembly buildings for } \\
\text { fewer than } 100 \text { persons } \\
\text { Emergency medical and other emergency facilities } \\
\text { not designated as post-disaster }\end{array}$ \\
\hline III & $\begin{array}{l}\text { Buildings of significant } \\
\text { importance for safety of } \\
\text { public and other } \\
\text { properties }\end{array}$ & $\begin{array}{l}\text { Hotels, offices, apartment buildings over } 10 \\
\text { storeys high, Factories and heavy machinery } \\
\text { plants over } 4 \text { storeys high } \\
\text { Shopping centres of over } 10000 \mathrm{~m}^{2} \text { gross area } \\
\text { excluding parking, Public assembly buildings for } \\
\text { more than } 100 \text { persons, } \\
\text { Airport terminals, principal railway stations }\end{array}$ \\
\hline IV & $\begin{array}{l}\text { Buildings of greater } \\
\text { importance with post } \\
\text { disaster functions for } \\
\text { civil protection }\end{array}$ & $\begin{array}{l}\text { Pre-schools, Schools, colleges, universities, Major } \\
\text { infrastructure facilities, e.g. power stations, } \\
\text { substations } \\
\text { Medical facilities for surgery and emergency } \\
\text { treatment, Hospitals, Fire and police stations, } \\
\text { Ambulance facilities } \\
\text { Buildings housing toxic or explosive substances in } \\
\text { sufficient quantities to be dangerous to the public } \\
\text { if released } \\
\text { Extreme hazard facilities (Dams etc.) }\end{array}$ \\
\hline
\end{tabular}

Table 2 - Proposed importance factors and corresponding return period values

\begin{tabular}{|c|c|c|c|c|}
\hline \multirow{2}{*}{$\begin{array}{c}\text { Importance } \\
\text { Class }\end{array}$} & \multirow{2}{*}{$\begin{array}{c}\text { Importance } \\
\text { factor }\left(\mathrm{\gamma}_{1}\right)\end{array}$} & \multicolumn{3}{|c|}{ Mean return period (in years) } \\
\cline { 3 - 5 } & $\mathrm{k}=2.5$ & $\mathrm{k}=3.0$ & $\mathrm{k}=4.0$ \\
\hline I & 0.80 & 272 & 243 & 195 \\
\hline II & 1.00 & 475 & 475 & 475 \\
\hline III & 1.50 & 1309 & 1603 & 2404 \\
\hline IV & 1.80 & 2065 & 2770 & 4986 \\
\hline
\end{tabular}




\subsection{Elastic response spectra}

Currently, there is no elastic response spectrum which represents ground motion for buildings in Sri Lanka. Therefore, for the purpose of seismic design of buildings in Sri Lanka, the most appropriate response spectrum is selected from the recommended Type 1 and Type 2 elastic response spectra given in the Euro Code 8 , the recommended elastic response spectrum in Indian seismic code (IS 1893-1: 2002) and the response spectra recommended in Australian code (AS 1170.4: 2007). The comparison of response spectra normalized by the peak ground acceleration for approximately equivalent soil types as recommended in the three codes above are shown in Figure 6a,b and c.

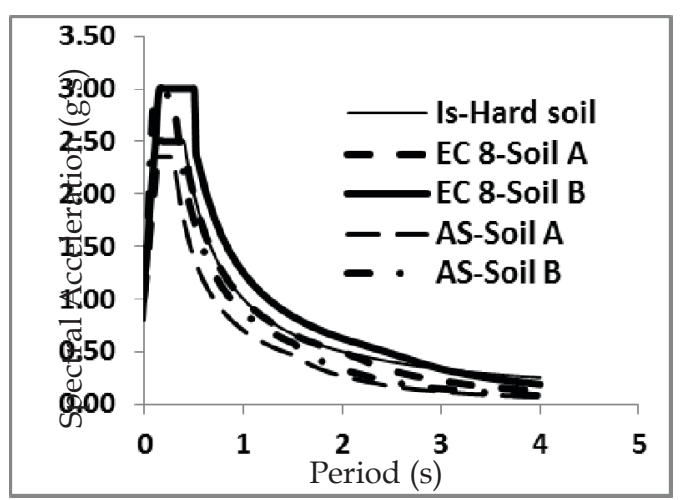

(a)

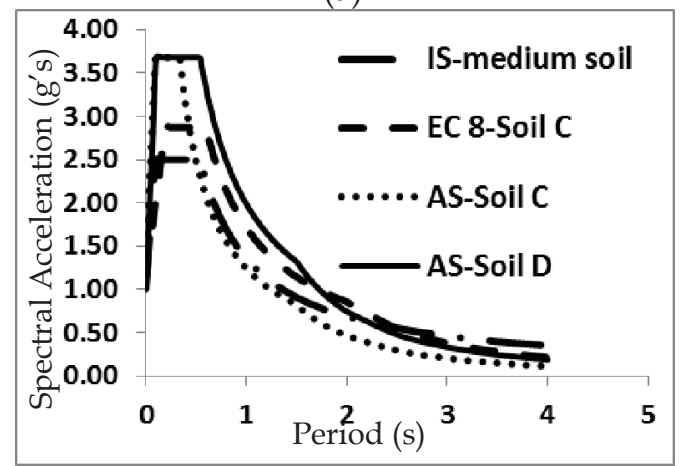

(b)

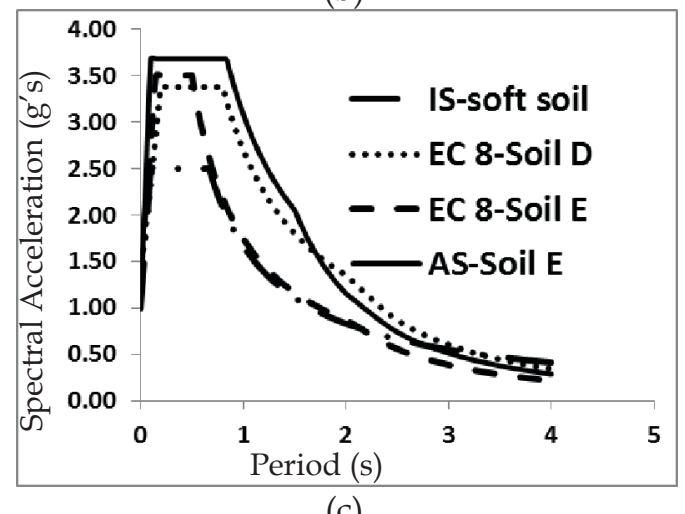

(c)

Figure 6 - Comparison of EC 8 Type 1 response spectra with IS 1893-1 and AS 1170.4 response spectra for the approximate equivalent soil types
However, within the scope of this study without a proper seismic hazard assessment for Sri Lanka it is not possible to predict which code approach would represent the local condition of Sri Lanka. On account of that, the use of Indian seismic code provision can be justified because it is a well-established seismic code in South Asian region and importantly Sri Lanka is situated close to India and it can be assumed that the seismicity of both countries would be approximately similar. Further, the response spectrum at rock site developed for the Colombo area [8] shows a reasonable match with the response spectrum recommended in the Indian seismic code (IS 1893-1: 2002) (See Figure 7).

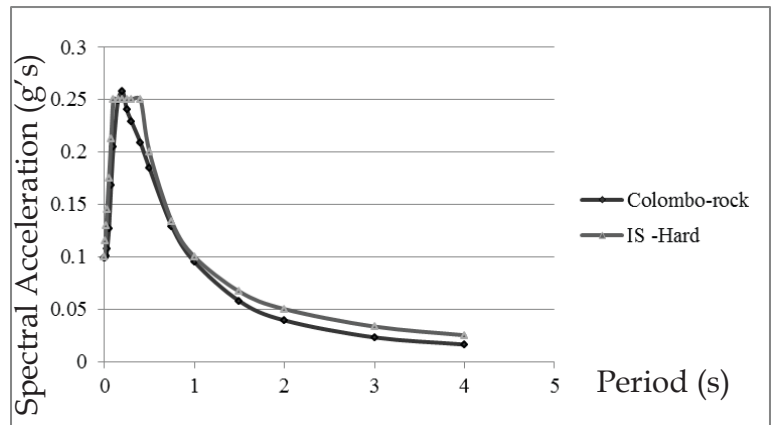

Figure 7- Response spectrum for Colombo at rock site and the corresponding response spectrum in IS 1893-1: 2002 [8]

Therefore, in the absence of a proper study, for seismic analysis of buildings IS 1893-1:2002 recommended elastic response spectra can be used. The expressions defining the response spectra for three soil types in IS 1893-1 are modified to suit the Euro code 8 as shown in Equations 3, 4 and 5 and the corresponding parameters are given in Table 3. The basic shape of the elastic response spectrum is shown in Figure 8.

$$
\begin{array}{cl}
0.00 \leq T \leq T_{B} & S_{a}=1+15 T \\
T_{B} \leq T \leq T_{C} & S_{a}=2.5 \ldots \ldots \ldots \ldots \\
T_{C} \leq T \leq 4.00 & S_{a}=S / T \ldots \ldots \ldots \ldots
\end{array}
$$

Table 3 - Soil types and corresponding parameters defining response spectra (IS 1893) modified to the format in EC 8

\begin{tabular}{|c|c|c|c|c|}
\hline Soil Type & $\mathrm{N}_{\text {SPT }}$ & $\mathrm{S}$ & $\mathrm{T}_{\mathrm{B}}$ & $\mathrm{T}_{\mathrm{C}}$ \\
\hline $\begin{array}{c}\mathrm{I} \\
\text { (Hard soil) }\end{array}$ & $>30$ & 1 & 0.1 & 0.4 \\
\hline $\begin{array}{c}\text { II } \\
\text { (Medium } \\
\text { soil) }\end{array}$ & $10-30$ & 1.36 & 0.1 & 0.55 \\
\hline $\begin{array}{c}\text { III } \\
\text { (Soft soil) }\end{array}$ & $<10$ & 1.67 & 0.1 & 0.67 \\
\hline
\end{tabular}




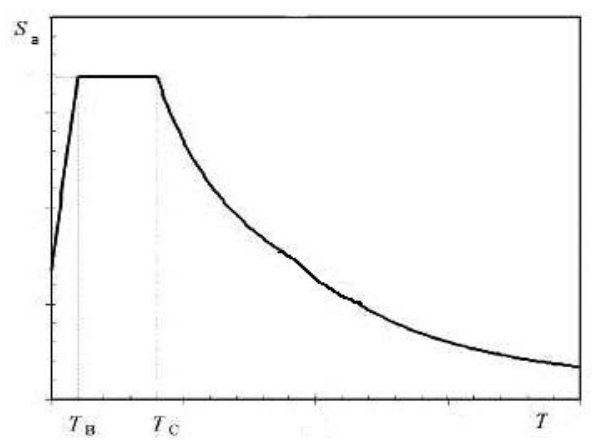

Figure 8-Basic shape of the horizontal elastic response spectrum

In elastic analysis methods, the elastic horizontal response spectrum is reduced to a design response spectrum which takes the ductile behaviour of buildings into consideration.

\section{Case Studies}

In order to understand the significance of seismic loading in designing buildings in Sri Lanka, two commonly found building types were analysed in accordance with the above proposed approach.

\subsection{Case study 1}

A three storey school building which is categorized as an important building due to its high consequences of failure during an earthquake was selected as the case study 01 .

The test building was analysed by the two linear elastic methods, static force method and modal response spectrum analysis method, prescribed in EC 8. All the analysis was performed by using ETABs software (CSI 2002. ETABS Integrated Building Design Software, Computers and Structures Inc. Berkley). The elevation and plan view of the building as well as the three dimensional model of the building used in the analysis are shown in Figure 9.

The elastic response spectrum and the design response spectrum for the test building are shown in Figure10.

According to the static lateral force method of analysis in EC 8, the seismic base shear for each horizontal directions of the building is determined as

$$
F_{b}=S_{d}\left(T_{1}\right) \cdot m \cdot \lambda
$$

The value of the ordinate of the design response spectrum, $S_{d}\left(T_{1}\right)$ corresponding to the fundamental period $T_{1}$ of the building is

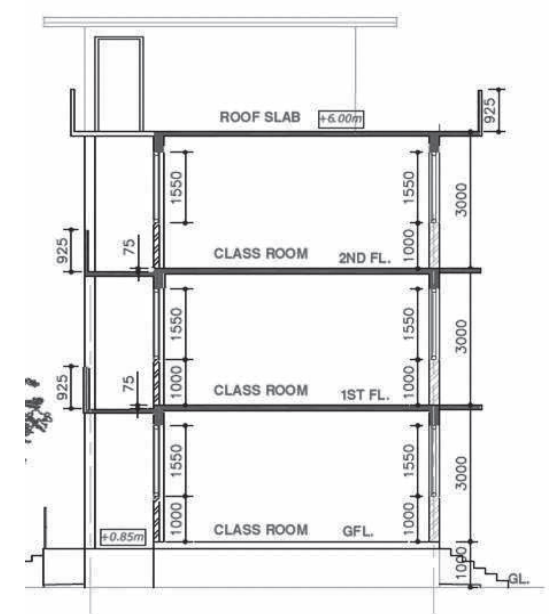

(a) Cross section of the building

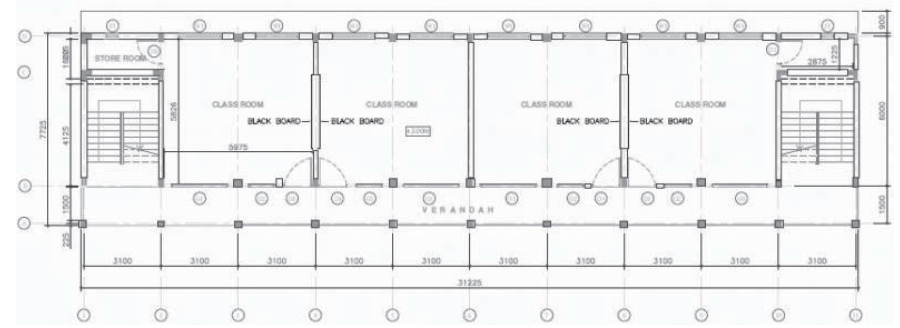

(b) plan view of the building

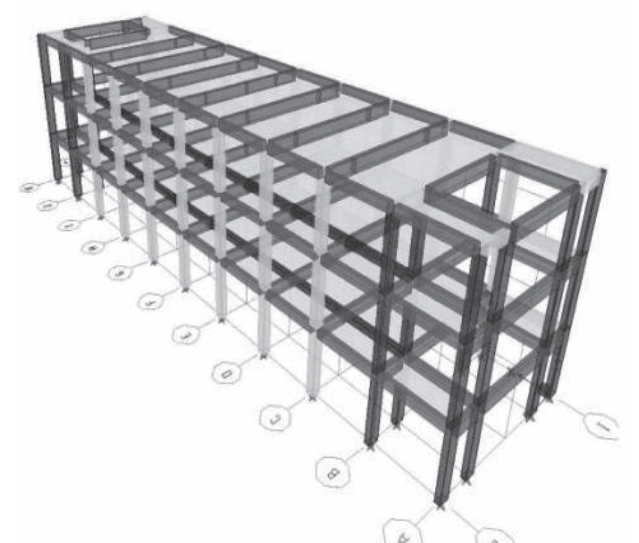

(c) Three dimensional model of the building

Figure 9 - Three storey school building

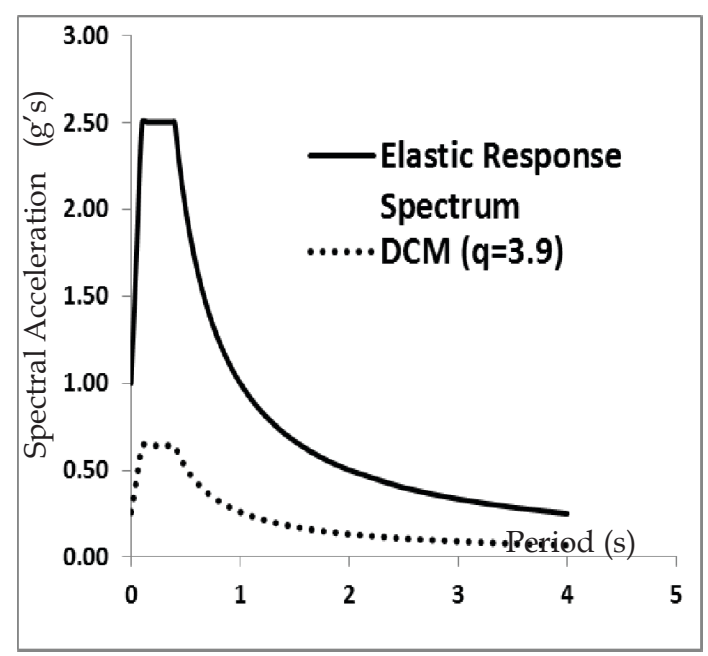

Figure 10 - Elastic and design response spectrum -Case Study 1 
obtained from the design response spectrum. Where $m$ is the seismic mass of the building and $\lambda$ is the correction factor which is given in EC 8 as 0.85 . The base shear force, $F_{b}$, is shown in Table 4.

Table 4 -Base shear for the test building-Case Study 1

(Lateral force method of analysis)

\begin{tabular}{|c|c|c|c|c|}
\hline $\begin{array}{c}\text { Fundament } \\
\text { al period } \\
\left(\mathrm{T}_{1}\right)\end{array}$ & $S_{d}\left(T_{1}\right)$ & $\mathrm{m}$ & $\lambda$ & $F_{b}$ \\
$(\mathrm{t})$ & $\lambda$ & $(\mathrm{kN})$ \\
\hline 0.39 & 1.13 & 1228 & 0.85 & 1179 \\
\hline
\end{tabular}

The seismic base shear values obtained from the static force method in EC 8 were compared with the same values obtained in accordance with two other seismic codes; AS 1170.4:2002 and IS 1893:2002 as shown in Table 5.

Table 5 - Comparison of base shear values obtained from different codes - Case Study 1 (Static lateral force method of analysis)

\begin{tabular}{|c|c|c|c|}
\hline & EC 8 & $\begin{array}{c}\text { AS 1170: } \\
2007\end{array}$ & $\begin{array}{c}\text { IS 1893: } \\
2002\end{array}$ \\
\hline $\begin{array}{c}\text { Base } \\
\text { shear }(\mathrm{kN})\end{array}$ & 1179 & 1175 & 846 \\
\hline
\end{tabular}

The test building was also analysed using the modal response spectrum analysis method as given in EC8. The seismic base shear values obtained from the analysis are given in Table 6.

Table 6 -Base shear for the test building-Case Study 1

(Modal response spectrum analysis)

\begin{tabular}{|c|c|c|c|}
\hline \multicolumn{2}{|c|}{$\begin{array}{c}\text { Fundamental Period } \\
(\mathrm{T})\end{array}$} & \multicolumn{2}{l|}{ Base Shear Force $(\mathrm{kN})$} \\
\hline x-dir & y-dir & x-dir & y-dir \\
\hline $1.31 \mathrm{~s}$ & $1.03 \mathrm{~s}$ & 336 & 426 \\
\hline
\end{tabular}

The difference between base shear values obtained from lateral force method of analysis and the modal response spectrum analysis is due to the two different fundamental period values obtained from the two analysis methods. In the modal response spectrum analysis, the masonry walls were considered having no contribution to the stiffness of the test building and hence, it gives a higher fundamental period.

\section{$5.2 \quad$ Case study 2}

An office building which is categorized as importance Class III (See Table 1) was analysed in accordance with the modal response spectrum analysis method in EC 8. The plan view, elevation and the three dimensional model of the test building used in the analysis are shown in Figure 11. All the analysis were performed using ETABs software (CSI 2002. ETABS Integrated Building Design Software, Computers and Structures Inc. Berkley).

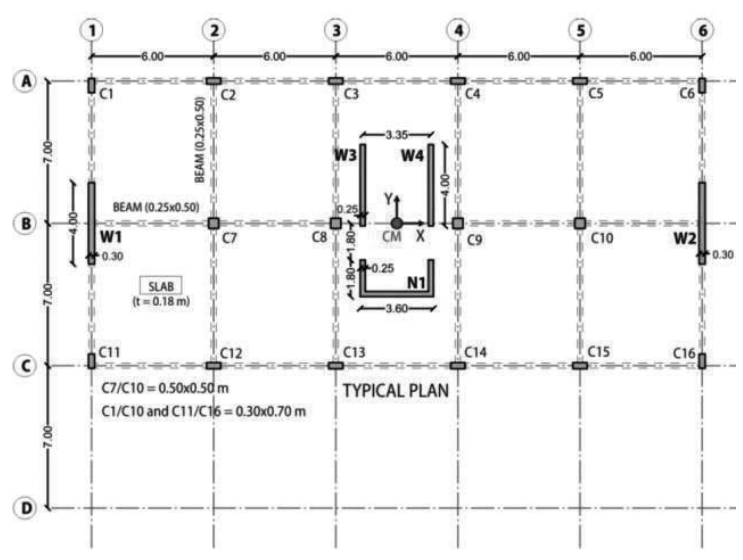

(a) Plan view of the floors above ground level

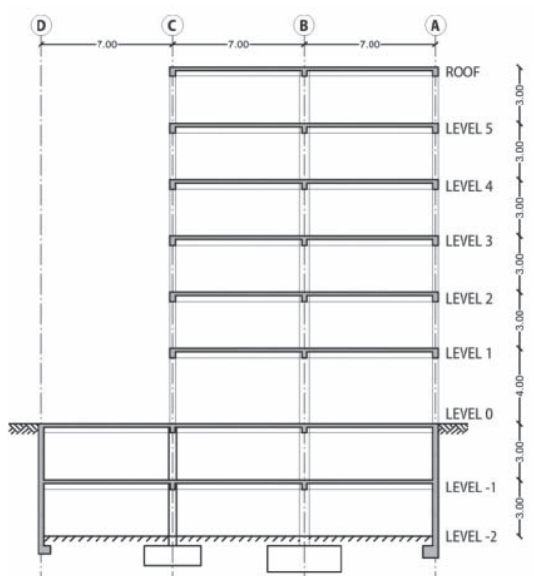

(b) Elevation of the building

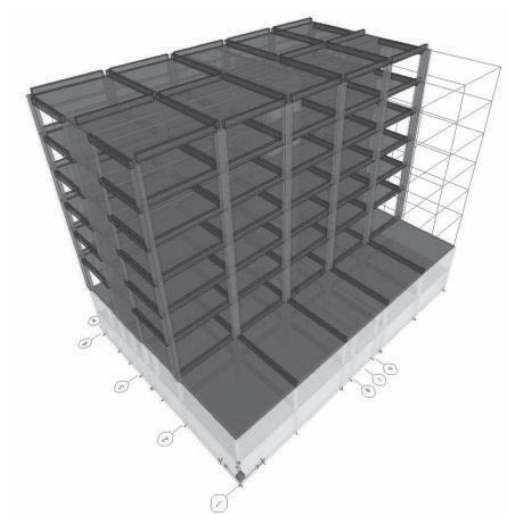

(c) Three dimensional model of the building

Figure 11 - Case Study 2 - Office Building 
The elastic response spectrum and the design response spectrum for the building are shown in Figure 12 and the seismic shear values obtained from the analysis are given in Table 7.

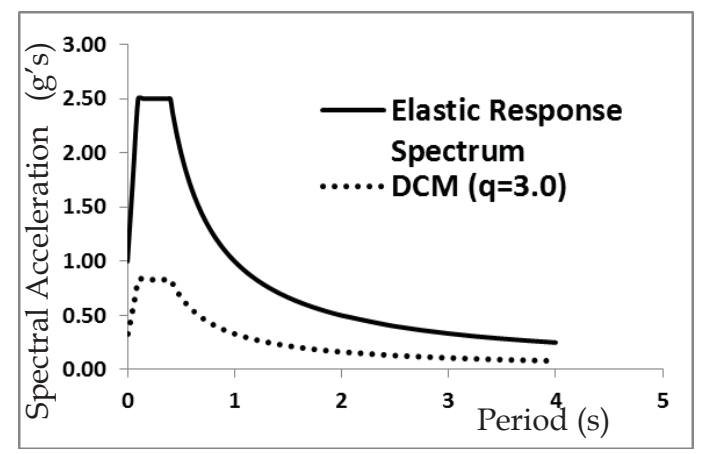

Figure 12 - Elastic and design response spectrum - Case Study 2

Table 7 - Seismic shear values at each storey level

\begin{tabular}{|l|c|c|}
\hline \multirow{2}{*}{ Storey Level } & \multicolumn{2}{|c|}{ Shear Force (kN) } \\
\cline { 2 - 3 } & $\begin{array}{c}\text { x-dir. } \\
(\mathrm{T}=1.0 \mathrm{~s})\end{array}$ & $\begin{array}{c}\text { y-dir. } \\
(\mathrm{T}=0.74 \mathrm{~s})\end{array}$ \\
\hline Roof & 201 & 254 \\
\hline Storey 5 & 353 & 463 \\
\hline Storey 4 & 446 & 600 \\
\hline Storey 3 & 524 & 713 \\
\hline Storey 2 & 603 & 814 \\
\hline Storey 1 & 672 & 891 \\
\hline Ground level & 672 & 891 \\
\hline Basement 1 & 672 & 891 \\
\hline
\end{tabular}

\section{Conclusions}

In the proposed national guidelines, a suitable approach for seismic analysis of buildings in Sri Lanka is proposed based on the Euro code 8 (EN 1998-1: 2004).

Several important parameters were determined for Sri Lanka based on the available seismic data. They are design peak ground accelerations for the three seismic actions having 475 year return period 1500 year return period and 2500 year return period for which the buildings in Sri Lanka are proposed to be designed. For instance, the peak ground acceleration for earthquake with 475 year return period has been assumed as 0.1g. Further, it is proposed to use the elastic response spectra developed for India in IS 18931 in the seismic analysis of buildings in Sri Lanka.
When other seismic analysis approaches are considered, the proposed (reference) peak ground acceleration value of $0.1 \mathrm{~g}$ seems to be a significant value. It necessitates most of the buildings to be designed for seismic loads and essentially for important buildings the value is increased further which resultsan explicit consideration of seismic loading.

The parameters proposed in this study especially peak ground acceleration values and the elastic response spectra can be replaced by the accurate values obtained through proper seismic studies for Sri Lanka in future. However, the proposed approach would still be used with the new values.

\section{Acknowledgements}

Financial support for this study was provided by Disaster Management Centre (DMC), Sri Lanka. The authors wish to thank Prof. M.T.R Jayasinghe \& Prof. W.P.S. Dias, University of Moratuwa, Prof. P.B.R. Dissanayaka \& Prof. K.G.H.C.N. Senevirathna, University of Peradeniya and Dr. K.K. Wijesundara, South Asia Institute of Technology and Medicine (SAITM) for their intellectual assistance.

\section{References}

[1] Durgesh, C. Rai (2000), "Future Trends in Earthquake-Resistant Design of Structures", CURRENT SCIENCE, VOL. 79, NO. 9, 10.

[2] FEMA 450-1, NEHRP Recommended Provisions for Seismic Regulations for New Buildings and other Structures, 2003 Edition.

[3] Euro code 8: Design of Structures for Earthquake Resistance - Part 1: General Rules, Seismic Actions and rules for Buildings, EN 1998-1: 2004.

[4] AS 1170.4 - 2007, Structural Design Actions, Part 4: Earthquake Action.

[5] IS 1893-1: (Part 1): 2002, Criteria for Earthquake Resistant Design of Structures, Bureau of Indian Standards.

[6] FEMA 450-2, Commentary NEHRP Provisions for Seismic Regulations for New Buildings and other Structures, 2003 Edition.

[7] Peiris L.M.N., "Seismic Hazard Assessment and Seismic Risk in Colombo", Risk Management Solutions, London, UK.

[8] Uduweriya, S. B., Wijesundara, K. K., Dissanayake, P. B. R., "Seismic Risk in Colombo - Probabilistic Approach", SAITM Research symposium on Engineering Advancements 2013 (SAITM - RSEA 2013) 